ECONOMICS

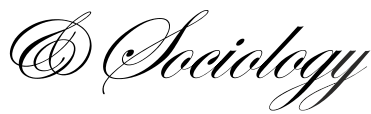

\author{
Barbara Chmielewska \\ Institute of Agricultural and Food \\ Economics - National Research \\ Institute, \\ e-mail:chmielewska@ierigz.waw.pl
}

Received: December, 2008

1st Revision: January, 2009

Accepted: March, 2009
Barbara Chmielewska, Influence of Social Benefits for Economic Situation of Farming Families, Economics \& Sociology, Vol. 2, No 1, 2009, pp. 111-117.

\section{INFLUENCE OF SOCIAL BENEFITS FOR ECONOMIC SITUATION OF FARMING FAMILIES}

\begin{abstract}
Farmer insurance contributions are lower than non-agricultural insurance contributions. Old-age pensions and pensions for farmers are lower than oldage pensions and pensions from non-agricultural social insurance system. Social benefits significantly influence the financial situation of farming families. The role of social benefits in the average farming family budget increases. Under conditions of European integration Poland is not obliged to introduce new insurance system, neither new social benefits nor to change the rules of calculating the amount of benefits. KRUS has become the institution co-operating with the relevant institutions from countries of European Union. This article includes also description of farmer's insurance in Poland called KRUS and its influence on income situations of polish farmers. It was made by using descriptive analysis. Organization structure, tasks and KRUS' rules of action as well as pension and retirement importance in income was described. This analysis shows also polish insurance system in comparison with another EU's countries. Polish farmers are covered by farmer's insurance system, which is serviced by an institution established solely for that purpose, that being the Agricultural Insurance Fund (KRUS).
\end{abstract}

JEL Classification: D1, Q12, Keywords: Social benefits, farming family budget, farmer's $\mathrm{J} 65$ insurance system, Agricultural Insurance Fund (KRUS)

\title{
Introduction
}

From the day of Poland's accession to European Union KRUS realizes tasks connected with the coordination of social security in the European Union countries. Not until 1978 was a system of social insurance for farmers introduced in Poland (The Act of 27 October, 1977) and as of 1991 (The Act of 20 December, 1990) the charge over the system was given to the Agricultural Insurance Fund (KRUS). It resulted in significant changes in the social insurance system. KRUS was obliged to realize tasks separated from the general social insurance system.

Farmers' social insurance provides two forms of covering by insurance both of which are financed according to separate rules:

- pensionary insurance, largely financed out of the state budget, additionally financed out of incomes from farmer's insurance contributions; 
- accident, sickness and maternity insurance, are covered only from farmer's contributions, collected by the Contribution Fund of the Farmers Social Insurance. The Fund is a legal person, President of KRUS performs a function of the management under the supervision of the Council of Farmers' Social Insurance.

\section{Old-age Pensions and Pensions for Farmers}

Social benefits significantly influence the situation of farming families. The poorest households (excluding the group with non-earning source of income ) are those which in the structure of incomes are characterized by the highest share of incomes from agriculture and social benefits. The role of social benefits in the average farming family budget increases significantly. In 1990 in farming households, participating in the analysis of family budgets conducted by CSO, the percentage of social benefits in the income amounted to $8.3 \%$ while in 2007 it increased to $16.1 \%$. The percentage is the highest for farming families compared to other groups of working families (Concise Statistical ..., 2007).

Old-age pensions and pensions for famers are considerably lower than the relevant benefits in the non-agricultural insurance system. In 2007 the average monthly old-age pension and pension for individual farmers amounted to PLN 814, it was by $37.6 \%$ lower than the relevant benefit in the non-agricultural insurance system (in 2000 it was lower by $31.2 \%$ ). In 2006 farmers benefits constituted only 30.2\% of the average monthly gross payment of national economy while non-agricultural insurance system benefits constituted considerably more, namely $47.5 \%$ (in 2000 the relation was analogous: $31.7 \%$ and $46.2 \%$ ) (Concise Statistical ..., 2007). The relation between farmer's benefits and non-agricultural benefits deteriorated.

The income from social benefits in general consists of $80 \%$ of social benefits and social insurance, inter alia, old-age pensions or disability pension, family pensions or maternity allowances and of $20 \%$ of social benefits which include inter alia unemployment allowances. In the structure of benefits the percentage of old-age pensions increased while the percentage of disability pensions decreased which was the result of the introduction of early retirement.

\section{Social Insurance System Tasks and Scope}

Under the Act on farmers' social insurance KRUS principal tasks are:

- service of the insured farmers and beneficiaries of KRUS (old age pensioners and pensioners) in the matters that concern covering farmers by social insurance as well as payment of the contributions for the insurance;

- granting and payment of pension benefits as well as accident, health and maternity benefits and also a non-insurance benefits issued together with the benefits from farmer's social insurance;

- realization of its own medical jurisdiction of two instances for the purpose of evidential proceedings which shall determine the rights of insured persons for receiving pension and compensation, where granting the rights for such benefits requires medical opinion on the state of health or the results of the occupational injury in agriculture. In the first instance medical statements are issued by experts, in the second instance by KRUS medical commissions;

- undertaking activities for the purpose of preventing occupational injuries in agriculture and agricultural occupational sickness, in particular: $<0\}$

- popularization of the knowledge of such treats as well as knowledge of occupational health and safety regulations among adults and children, 
- analyzing the causes and circumstances of an occupational accidents and sicknesses in agriculture,

- organizing trainings with the purpose of providing knowledge of occupational threats and safety regulations concerning working on the farm,

- undertaking efforts to popularize competent production of safe technical equipment for farmers as well as protection wear used in agriculture;

- free and voluntary medical rehabilitation for an insured persons and KRUS beneficiaries who are threatened by complete and permanent inability to work or who temporarily displays complete inability to work on the farm $<0\}$ The rehabilitation is conducted by KRUS centres and sanatoria which co-operate with KRUS (during holiday season KRUS also conducts rehabilitation sessions for farmer's children);

- supporting voluntary insurance;

- servicing health insurance, according to the Act 27 August 2004 on health insurance benefits financed from public funds (www.krus.gov.pl).

During the first year of KRUS activity the number of persons entitled for farmer's insurance amounted to 1750.0 thousand. Until 2007 it increased to 1598.2 thousand. The number of KRUS beneficiaries decreased in the given period from 1790.6 thousand to 1508.1 thousand. KRUS covers over 2615.5 thousand farmers and their household members who actively participate in the agricultural works, as well as total of beneficiaries and their families submitted to health insurance.

In 2004 significant changes in the farmer's insurance system were introduced, resulting inter alia from Poland's accession to European Union (The Act of 2 April, 2004). The amendment of the Act stated that from 2004 the contribution for insurance from a person entitled for farmer's social insurance who simultaneously conducts non-agricultural commercial activity (which is subject of annual tax payment exceeding PLN 2755) or who participates in such activity shall pay an insurance contribution twice higher than a person who does not conduct any of such activity.

Table 1. The number of insured persons and KRUS beneficiaries and the amount of farmer's insurance contributions

\begin{tabular}{|l|l|l|l|l|l|}
\hline \multirow{2}{*}{ Years } & \multicolumn{3}{|c|}{ Number of persons in Thousand } & \multicolumn{2}{c|}{$\begin{array}{c}\text { Contribution for insurance } \\
\text { PLN/quarter ** }\end{array}$} \\
\cline { 2 - 6 } & insured persons & $\begin{array}{c}\text { including: } \\
\text { persons } \\
\text { conducting } \\
\text { non-agricultural } \\
\text { activity } *\end{array}$ & beneficiaries & pension & $\begin{array}{c}\text { accident, } \\
\text { sickness } \\
\text { and maternity } \\
\text { insurance }\end{array}$ \\
\hline 1991 & 1750.0 & $\mathrm{x}$ & 1790.6 & $\mathrm{x}$ & $\mathrm{x}$ \\
\hline 1995 & 1426.6 & $\mathrm{x}$ & 2049.2 & $64.2-73.0$ & $30-42$ \\
\hline 2000 & 1452.4 & 70.7 & 1887.2 & $135.3-141.2$ & $54-54$ \\
\hline 2003 & 1589.3 & 98.7 & 1755.3 & $159.9-165.8$ & $54-54$ \\
\hline 2004 & 1540.1 & 115.2 & 1708.6 & $165.8-168.8$ & $54-60$ \\
\hline 2005 & 1581.9 & 48.1 & 1661.8 & $168.8-168.8$ & $60-72$ \\
\hline 2006 & 1615.3 & 65.7 & 1585.9 & $168.8-179.0$ & $72-72$ \\
\hline 2007 & 1598.2 & 79.5 & 1508.1 & $179.8-179.0$ & $72-72$ \\
\hline 2008 & $\mathrm{x}$ & 71.3 & $\mathrm{x}$ & $179.0-191.0$ & $78-78$ \\
\hline
\end{tabular}

$*$ State from the first quarter of the given year. $* *$ Sums for the first and the fourth quarter of the given year. Source: www.krus.gov.pl. 
The amendment had negative impact on the economical state of many families in particular those who manage small agricultural holdings and also conduct non-agricultural activity. It also became an obstacle for those farmers who wanted to increase their incomes by conducting non-agricultural activity. As the result of passing of the Act the total number of persons insured by KRUS decreased by $3.1 \%$ in 2003-2004 while the number of persons covered by farmer's social insurance who simultaneously conduct non-agricultural activity decreased even by 58,3\% (from 115.2 thousand to 48.1 thousand). The number of KRUS beneficiaries and the amount of contributions are shown in the Table 1.

More than a half of the total number of persons insured by KRUS are holders of agricultural holdings of the area ranging from 2 to 12 ha (see Table 2).

Table 2. The number of farmers covered by social insurance according to the area of agricultural holdings

\begin{tabular}{|l|l|l|l|l|l|l|l|}
\hline \multirow{2}{*}{$\begin{array}{l}\text { Area } \\
\text { of } \\
\begin{array}{l}\text { agricultural } \\
\text { holdings }\end{array}\end{array}$} & \multicolumn{3}{|l|}{ Number of insured persons in thousand * } & \multicolumn{2}{l}{$\begin{array}{l}\text { Percentage \% of the total } \\
\text { number of insured persons }\end{array}$} \\
\cline { 2 - 9 } & 2003 & 2004 & 2007 & $\frac{2007}{2003}$ & 2003 & 2004 & 2007 \\
\hline 0 to 1 & no data & 147.6 & 218.3 & $\mathrm{x}$ & $\mathrm{x}$ & 9.6 & $13.7 * *$ \\
\hline 1 to 2 & 309.9 & 296.3 & 303.1 & 97.8 & 20.0 & 19.2 & 19.0 \\
\hline 2 to 5 & 440.6 & 420.5 & 415.4 & 94.3 & 27.0 & 27.3 & 26.0 \\
\hline 5 to 10 & 360.3 & 348.2 & 336.8 & 93.5 & 22.0 & 22.6 & 21.1 \\
\hline 10 to 20 & 215.0 & 209.8 & 212.0 & 98.6 & 14.0 & 13.6 & 13.3 \\
\hline 20 to 50 & 72.5 & 73.3 & 85.1 & 117.4 & 5.0 & 4.8 & 5.3 \\
\hline above 50 & 12.3 & 12.8 & 17.9 & 145.5 & 1.0 & 0.8 & 1.1 \\
\hline $\begin{array}{l}\text { Special } \\
\text { sectors }\end{array}$ & $\begin{array}{l}(\text { approx. } \\
2 \%)\end{array}$ & 31.6 & 9.6 & $\mathrm{x}$ & $\mathrm{x}$ & 2.1 & 0.6 \\
\hline Total & 1589.3 & 1540.1 & 1598.2 & 100.5 & $\mathrm{x}$ & $\mathrm{x}$ & $\mathrm{x}$ \\
\hline
\end{tabular}

* State from the day of 31 December given year. ** Including persons who receive early retirement. Source: www.krus.gov.pl.

In 2003-2004 the number of farmers managing agricultural holdings of the area exceeding 20 ha, insured by KRUS, increased while the number of insured owners of smaller agricultural holdings decreased (most significantly in the areal groups 2-10 ha). Within those groups of agricultural holdings occurred the most significant decrease of the number of farmers covered by farmer's insurance (from 5.7 to $6.5 \%$ ). Most of all it resulted from a change of rules concerning insurance of persons conducting non-agricultural activity since persons engaged in such activity are mainly holders of smaller agricultural holdings .

CSO data states that the average area of the agricultural holding, where the main source of income is a non-agricultural activity or there are many sources of income, is estimated at 5.0-5.5 ha (The characteristics ..., 2006). It shows that more than 30 thousand agricultural holdings of the area ranging from 2 to 10 ha changed the form of insurance from KRUS to ZUS (Social Insurance Institution - non-agricultural system) which was followed by higher contributions and increase of "obligatory" cost of maintenance.

\section{KRUS Organisational Structure}

KRUS organisational structure constitutes of: Head office, which is situated in Warsaw, 49 regional departments and 220 local agencies, including other organizational units 
such as 5 Centres for Rehabilitation and 2 KRUS Training and Recreational-Rehabilitation Institutions for Farmers.

In Head Office of KRUS 197 persons are employed, in regional departments 6261 persons, who service more than 1552.5 thousand of insured famers and 1667.3 thousand of beneficiaries (old-age pensioners and pensioners) (Word Bank .., 2005). In the report: Assessment of organisational structure of KRUS issued by World Bank Group in 2005, the state of employment in the Fund was assessed as favourable. "However, we are aware - as it is stated in the Report - that while additional tasks assigned to KRUS over the years have been undertaken and without additional resources being assigned. We are also conscious of the fact that HR Department in Head Quarters does not scrutinise staffing levels locally as they are managed under the administration budget secured by each Regional Manager. While this system operates well and maybe to the advantage of the regional and local office managers we have no evidence to say that they are overstaffed. Straight comparisons with other institutions might suggest that staffing levels are comfortable." Experts of the World Bank Group compare the level of employment in KRUS with the level of employment in a similar institutions in Lithuania and Ireland. State Social Insurance Fund (Lithuania) with a client base of 1 billion pensioners and over 1 billion insured employs less than 3000 people, while Ministry of Social and Family Affairs (Ireland) which covers social insurance and assistance (with a client base of 1 billion pensioners and over 1 billion insured) employs 4400 people. It was recommended in the Report "that staffing levels be monitored more by Head Quarters with a view to determining in the future the actual staffing requirements needed to provide a good service locally at the right cost (Word Bank ..., 2005).

Since KRUS transfers health contributions to NHIF on behalf of farmers also the effectiveness of its activity in that matter was assessed. "These transfers to the NHIF - states the Report - are done monthly by KRUS from the State budget allocation received. Tax is deducted at source by KRUS...and this amount is transferred to the State Tax Administration on behalf of farmers receiving old age pensions and disability pensions. This is an inclusive approach by KRUS that secures maximum compliance for the National Health Insurance Fund and the State Tax Administration. This approach is an excellent example of maximising resources to the advantage of all interested parties, farmers, KRUS, National Health Insurance Fund and the State Tax Administration" (Word Bank ..., 2005).

Whether the amounts of insurance contributions are adequate to the capacity to pay is another question. Many would agree that those farmers who can contribute more should do so and the additional revenue generated should be used to benefits all. In such case it would be crucial to maintain the minimum collection levels, for instance the current flat rate contribution (30\% of minimum famer's old-age pension) should be the minimum contribution payable by farmers and thereafter income related contributions should be payable by farmers based on their ability to pay. The system should clearly identify farmers capacity to pay and facilitate the development of agricultural potential, since establishing taxes and contributions which are not adequate to the actual level of farmer's income will hardly lead to improvements in the system but will only lead to indebtedness by farmers that ultimately will serve no purpose, other than to worsen their economic and social situation.

Whether income related contributions should attract income related pensions is also an issue for debate. Many automatically assume that one justifies the other. However, in reality this is not so clear, since income related pensions and benefits are expensive and costly to administer. In most instances the income related element is not significant and cannot be justified in terms of the cost of administration and the amount of benefit accruing to the beneficiary. Moreover, wealthier farmers should be encouraged to seek additional pension cover through the selection of pension funds scheme currently available. 
Ireland is an example of a country that does not pay earnings related pensions or benefits, even though an income related contribution applies to the social insurance system. At the same time United Kingdom has an income related contribution and income related pensions in place for over 20 years. Current analysis indicate that UK has now realised that financing old-age pension for the future is inadequate and has to review their approach to try to encourage individual savings to improve the situation in the future. It indicates that income related pensions are not the straightforward answer or solution (Word Bank ..., 2005).

Introducing obligatory farmer's social insurance system and establishing and institution for servicing the system (that being KRUS in Poland) as well as substantial participation of the state budget in financing benefits are the activities designed for the benefit of economic safety (although on the low level) of families connected with agriculture, particularly in the view of the fact, that considerable number of insured persons and beneficiaries of farmer's social insurance system manages agricultural holdings of area not exceeding 1-2 ha and one out of four agricultural holdings does not conduct agricultural activity (Goraj, Jagła, 2005). Farmer's social insurance system constitutes a link between the significance of agriculture for the national economy and living conditions of farming population, and through diversified remedial measures it supports reducing poverty and concealed unemployment, in particular related to persons passing over unprofitable agricultural holdings. Such is the role of social insurance system in countries where agriculture is on the higher level of development than in Poland, for instance in Austria where "being a certain provider for generations the system enabled smooth transition from shrinking agricultural sector to other sectors of economy" (Tryfan, 2005).

Presently the reform of farmer's social insurance system and the adaptation of the system to changing conditions is being discussed in Poland. On 1 October 2008 the Government approved the Reform Project. From January 2009 owners of agricultural holdings with an arable area not exceeding 50 ha shall pay KRUS contributions on the previous level, that being $10 \%$ of the minimum old-age pension (PLN 64 monthly); the contributions for farmers, who manage agricultural holdings with an arable area exceeding 50 ha shall be additionally increased: by $12 \%$ of the minimum old-age pension in case of agricultural holdings with an arable area ranging from 50 to 100 ha (by PLN 76); by 24\% in case of agricultural holdings with an arable area ranging from 100 to 150 ha (by PLN 153); by $36 \%$ in case of agricultural holdings with an arable area ranging from 150-300 (by PLN 229) and by $48 \%$ in case of agricultural holdings with an arable area exceeding 300 ha (by PLN 305). The Reform will cover approx. $1.1 \%$ of insured by KRUS.

\section{Farmer's social insurance system in Poland against EU requirements}

According to the amended act, from May 2004 persons entitled to be insured by KRUS are Polish farmers as well as citizens of EU member states who personally and on their own account conduct the agricultural activity on the farm situated in the Republic of Poland. Under the conditions of European integration KRUS has become a linking institutions cooperating with relevant linking institutions from EU countries.

In each European Union country separate social insurance systems and health insurance systems operate. Poland is not obliged to introduce a new insurance system, implement a new insurance benefits nor to change current rules of calculating the amount of benefits. Just as other EU countries Poland retained the right to decide who may be insured, what benefits may be granted by the insurance system as well as the right to define the rules of calculating and issuing the benefits.

Due to the general public acceptance of an internal insurance systems in particular member states EU did not introduced uniform social insurance system. However, all the 
member states and their insurance institutions were obliged to meet certain rules and requirements which purpose was to ensure coordination between all the social insurance systems. Rules for coordination of social insurance system are applicable for all domestic rules concerning: sickness and maternity, work injury, occupational sickness, disability pensions, benefits resulting from death of the bread-winner, benefits in case of death, family allowances.

\section{Summary}

Old-age pensions and pensions for farmers are lower than old-age pensions and pensions from non-agricultural social insurance system.

Social benefits significantly influence the financial situation of farming families. The role of social benefits in the average farming family budget increases.

Polish farmers are covered by farmer's insurance system, which is serviced by an institution established solely for that purpose, that being the Agricultural Insurance Fund (KRUS).

Farmer insurance contributions are lower than non-agricultural insurance contributions.

Under conditions of European integration Poland is not obliged to introduce new insurance system, neither new social benefits nor to change the rules of calculating the amount of benefits. KRUS has become the institution co-operating with the relevant institutions from countries of European Union.

\section{Resources:}

1. The characteristics of farming households in 2005, (2006), CSO, Warsaw.

2. Goraj L., Jagła W., (2005), Farming households, agricultural activity vs. obligatory insurance in KRUS. Insurance in Agriculture. Materials and Studies, No 1.

3. Concise Statistical Yearbook of Poland 2008, (2007), CSO, Warsaw.

4. World Bank Group Report titled Assessment of organisational structure of KRUS. Poland Post-Accession Rural Support Project (PARSP) of 19 July 2005, Garry Fitzpatrick - consultant, Annex A.

5. Tryfan B., (2005), Social Insurance of Austrian farmers in the prospect of rural areas development. Insurance in Agriculture. Materials and Studies, No 1.

6. The Act of 27 October 1977 on retirement benefits insurance and other benefits for farmers and their families (Dz.U. No 32, item 140).

7. The Act of 20 December 1990 on farmers' social insurance (full text: Dz.U. 2008 No 50 item 291 with later amendments).

8. The Act of 2 April 2004 on the amendment of the Act of farmers' social insurance and some other Acts (Dz.U. No 91/2004, item 873 and Dz.U. No 150/2005, item 1248).

9. www.krus.gov.pl. 